2nd International Conference Global Ethics -Key of Sustainability (GEKoS) | May 14, 2021 | Bucharest, Romania

\title{
Human Resources' Resistance to Change - from Routine to Entrepreneurship ideas
}

\author{
Ana-Maria NICOLAE (STAN)
}

https://doi.org/10.18662/lumproc/gekos2021/12

How to cite: Nicolae (Stan), A.-M. (2021). Human Resources' Resistance to Change - from Routine to Entrepreneurship Ideas. In A. Grigorescu \& V. Radu (vol. ed.), Lumen Proceedings: Vol. 15. 2nd International Conference Global Ethics - Key of Sustainability (GEKoS) (pp. 134-146). Iasi, Romania: LUMEN Publishing House. https://doi.org/10.18662/lumproc/gekos2021/12 


\title{
Human Resources' Resistance to Change - from Routine to Entrepreneurship Ideas
}

\author{
Ana-Maria NICOLAE (STAN) ${ }^{1}$
}

\begin{abstract}
Nowadays, change has become a constant presence inside the organizations and its existence in organizational life has proved to be necessary for its evolution. The term "change" conveys the idea of renovating or transforming an existing thing by adding some values or reducing others. This way, it can be said that change is a process of organizational transformation-especially regarding human resources and overcoming the resistance to change.

No one is immune to change and this process affects all members of an organization, either in a positive or negative way. On one hand, it can bring together the members of an organization to achieve a common objective, on the other hand it may be a disruptive factor, a divisional factor and a source of conflict. Although the change may mean something different for different people, it is not something new.
\end{abstract}

Keywords: management of change, resistance to change, entrepreneurship.

\footnotetext{
${ }^{1}$ Ph.D. Student, "Valahia” University of Targoviste, Romania, annanicolae@yahoo.com
} 
Ana-Maria NICOLAE (STAN) | Lumen Proceedings 15 | GEKoS 2021

\section{Introduction}

The recent period, marked by the global health crisis triggered by the emergence of the SARS-CoV-2 virus, has forced us to become the witness of a radical change, involving organizational, structural and functional changes, by rethinking the use of information technology, and implicit the functioning of the organization, with an impact on the values and culture of the organizational entity.

The theme of change in the organizational field is all the more relevant as changes and reforms are taking place in society, which is also happening in the current Romanian educational space. In human capital management, new ideas, frameworks and theories have sprung up to replace old ideas, frameworks and theories. However, that does not mean that "the old theory cannot be applied in the real world." (Rusmingsih et al., 2021) The ability to adapt human resources to change is a key factor in the success of the organization, and, in an increasing number of cases, a condition for mere survival. Organizational change efforts "have become ubiquitous in the work of today's organizations.” (Oxman \& Smith, 2003).

\section{Problem Statement}

The change can occur in an organization from the most conceptual level (e.g. in mentality or culture) to the most basic level (for example, to a piece of equipment or to a person).

Organizational changes are about "reducing efforts, improving the organizational efficiency, increasing flexibility and putting the organization in a position to be able to respond to the market requirements." (Kotter, 2007). Although organizations want members who are willing to make efforts for change, research shows that people have "the predisposition to view the change either positive or negative." (Oreg, 2003) When we talk about organizational culture we must consider two aspects: perceptible factors (behavior, ethics) and personal factors (feelings, temperament, beliefs), together creating the organization its own ethical identity (Pruteanu, 2020).

In this context, although the subjects of change usually see the negative change, organizational change has become unavoidable for companies wishing to remain competitive in their environments (Beckhard, 1975; Dutton et al., 2001; Kotter, 2007). This is demonstrated by the permanent change in the business market, restructuring and changes in leadership, which are common in the work of organizations nowadays. 
Even with greater attention to change, recognizing its need and understanding the importance of managing the process effectively is still a significant challenge for organizations.

Schein (1996) said that the change implies "preserving the organizational identity through a difficult process of unlearning-relearning by restructuring thoughts, perceptions, sentiments and attitudes." The organizations are subjected to this unlearning "to help them cope with a new and much more challenging business environment." (Kotter, 2007) .

It is important that efforts of change focus on the individual, as individuals execute strategies, so their reactions to any organizational change become critical to the success of the initiative (van Dam et al., 2008). Human change (Schein, 1996) requires "careful navigation to move individuals and groups" from resistance to acceptance, from routine to new entrepreneurial ideas.

Zander (1950)defines resistance to change as a "behavior that is designed to protect an individual from the effects of actual or imaginary changes".

Some researchers and leaders of change view resistance as an undesirable effect on organizational change, and other researchers consider resistance as a mechanism for challenges. Smollan (2006) suggests that "the assumption of the leader of change that there will be resistance, makes resistance to change a prophecy that is fulfilled".

When we talk about organizational change we notice that employees tend to resist change when do not fully understand the change and its implications (Kotter \& Schlesinger, 1979), when there is a potential threat to an individual's position of power within the organization (Kotter \& Schlesinger, 1979; Wanberg \& Banas, 2000), when the changes dispute the cultural assumptions (Gersick, 1991; Kotter, 2007; Nadler \& Tushman, 1989; Schein, 1992), and when there is the potential to lose something of value (Kotter \& Schlesinger, 1979).

The common reasons for resistance to change demonstrate that employees are usually not afraid of change per se, but the negative consequences that come with the change (Oreg, 2006).

Resistance to change "is a common part of organizational change, which also affects today's educational organizations"(Foster, 2010, p. 3).

Changing practices in school organizations actually includes different approaches of curricula, management teams, school programs, children and teachers. For these frequent changes to be implemented effectively, there must be flexibility from the educational institutions so that they can propose organizational strategies while facing change (Rosenblatt, 2004). 
The nature and the rhythm of changes brought by the coronavirus pandemic over the past year have called for important changes in the education system. Thus, since March, all of the educational institutions have moved their activity online. The fast and unplanned transition to digital education has put pressure on schools to implement rapid changes, both in the way they are organized and function, and in their own organizational structure. Under the circumstances caused by the COVID-19 crisis, the educators and learners have been put in a position to prove their potential for distance teaching and learning and their ability to cope with its limitations.

These pressures have led to different responses from members of school organizations. One of the typical responses is resistance to change.

\section{Aims of the research}

While most studies focused on contextual or situational factors as a history of resistance to change, others (Judge et al., 1999; van Dam et al., 2008; Oreg, 2003; Oreg, 2006; Wanberg \& Banas, 2000) focused on the mood factors contributing to the resilience. This operative approach to resistance says that an individual has pre-defined mental maps (Judge et al., 1999) which determine how he or she responds to change.

For this case study I have followed what Creswell (2009) considers to be "a numerical description of the of the opinions, ideas, and views of a population by questioning a representative sample of that population".

Hypothesis: More you perceive the work as a routine, the more resistance to change raise.

\section{Research Methods}

To measure resistance to human resource change we used the scale of resistance to change developed by Shaul Oreg (2003). The scale of resistance to change is a 17 -question questionnaire that includes statements about people's overall orientation to change using a 5-point Likert scale:

$5=$ Strongly agree

4= Agree

$3=$ Neutral

$2=$ Disagree

$1=$ Strongly disagree

The change resistance scale measures four personality-based layouts reflected in the following dimensions (Oreg, 2003): 
- routine search;

- emotional reaction;

- short-term focus;

- cognitive rigidity.

The routine search factor includes questions 1 to 5 and measures how a person prefers consistency or lack of novelty in his or her daily routine.

The emotional reaction includes questions 6 to 9 and measures the reaction to the imposed change and its results include stress and tension.

The short-term focus includes questions from 10 to 13 and pays particular attention or emphasis on the immediate consequences of the change.

Cognitive rigidity includes questions from 14 to 17 and it measures "the ease and frequency that the mind of individuals changes" (Oreg, 2003).

Demography:

This section covers the gender, career level, tenure, professional experience and education of the participants as shown in Table 1. The sample studied consists of teachers from two pre-university education organizations. 50 questionnaires were distributed. Of these, 44 have been completed, but only 41 have been fully completed. We therefore consider that the response rate above $50 \%$ is enough to reach the confidence level of the results (Babbie, 1990).

Table 1. Statistics of demographic variables $(\mathrm{N}=41)$

\begin{tabular}{llcc}
\hline Characteristics & \multicolumn{1}{c}{ Level } & Number & Percentage \\
\hline \multirow{2}{*}{ Gender } & Male & 8 & $19,51 \%$ \\
& Female & 33 & $80,49 \%$ \\
\hline \multirow{4}{*}{ Position in } & Kindergarten & 7 & $17,07 \%$ \\
organisation & teacher & & \\
& Primary school & 6 & $14,63 \%$ \\
& teacher & 24 & $58,54 \%$ \\
& Teacher & 4 & $9,76 \%$ \\
\hline \multirow{5}{*}{ Seniority } & Principal & 5 & $12,20 \%$ \\
& Less than 1 year & 5 & $12,20 \%$ \\
& 1 year - 5 years & 12 & $29,27 \%$ \\
\multirow{2}{*}{ Tenure } & 5 years - 10 years & 13 & $31,71 \%$ \\
& 10 years - 20 years & 6 & $14,63 \%$ \\
\hline \multirow{5}{*}{ Education } & More that 20 years & 34 & $82,93 \%$ \\
& Tenure teacher & 7 & $17,07 \%$ \\
\hline & Substitute teacher & 4 & $9,76 \%$ \\
& Highschool studies & 10 & $24,39 \%$ \\
& Bachelor's level & 26 & $63,41 \%$ \\
& Master's level & 1 & $2,44 \%$ \\
\hline
\end{tabular}




\section{Findings}

According to Oreg (2003), each of the four dimensions captures many aspects that predispose human resources in an organization to withstand change. Oreg (2003) adds that these aspects can be studied in the light of people's emotional and cognitive behaviors towards resistance to change, such as:

- behavioral size is the tendency of people, in general, and employees, in particular, to create routines;

- the emotional size includes two dimensions:

- Affective dimension: refers to the stress and anxiety of people when they have to face change.

- The short-term focus shows the fact that people tend to be distracted by short-term disadvantages involved in change, tending to avoid the rational choice of long-term benefit.

- the cognitive size shows the speed that people change their mind.

When there are links between these factors, one can see the existence of a general willingness to resist organizational change (Oreg, 2003).

Below are the statistical processing of the results obtained from the centralization of the questionnaires:

Table 2. The score for the routine search dimension

\begin{tabular}{|c|c|c|c|}
\hline Dimension & Items & $\begin{array}{l}\text { Average of } \\
\text { the values }\end{array}$ & $\begin{array}{l}\text { Standard } \\
\text { deviation }\end{array}$ \\
\hline \multirow{5}{*}{$\begin{array}{l}\text { ROUTINE } \\
\text { SEARCH }\end{array}$} & $\begin{array}{l}\text { I like to have a routine day } \\
\text { after a full day of unexpected } \\
\text { events }\end{array}$ & 2,3 & 1,09 \\
\hline & $\begin{array}{l}\text { I try not to form a stable } \\
\text { routine }\end{array}$ & 2,09 & 0,84 \\
\hline & $\begin{array}{l}\text { In general, I believe that the } \\
\text { changes are a bad thing }\end{array}$ & 2,14 & 0,71 \\
\hline & $\begin{array}{l}\text { I prefer old, familiar } \\
\text { activities, compared to some } \\
\text { new and different ones }\end{array}$ & 2,24 & 0,72 \\
\hline & I prefer routine to novelty & 1,92 & 0,74 \\
\hline
\end{tabular}


Ana-Maria NICOLAE (STAN) | Lumen Proceedings 15 | GEKoS 2021

Table 3. The score for the emotional reaction dimension

\begin{tabular}{|c|c|c|c|}
\hline Dimension & Items & $\begin{array}{l}\text { Average of } \\
\text { the values }\end{array}$ & $\begin{array}{l}\text { Standard } \\
\text { deviation }\end{array}$ \\
\hline \multirow{4}{*}{$\begin{array}{l}\text { EMOTIONAL } \\
\text { REACTION }\end{array}$} & $\begin{array}{l}\text { When things don't go as } \\
\text { planned, I'm getting stressed }\end{array}$ & 2,63 & 1,22 \\
\hline & $\begin{array}{l}\text { I feel uncomfortable when } \\
\text { performance criteria change } \\
\text { during work even if it means } \\
\text { better results without extra } \\
\text { work. }\end{array}$ & 2,85 & 1,18 \\
\hline & $\begin{array}{l}\text { If I had been informed that } \\
\text { an important change was } \\
\text { taking place at work, I would } \\
\text { have felt stressed }\end{array}$ & 3,09 & 1,12 \\
\hline & $\begin{array}{l}\text { When I find out about } \\
\text { changing plans, I'm a little } \\
\text { tense }\end{array}$ & 3,36 & 1,20 \\
\hline
\end{tabular}

Affectivity is the way people express their stress and insecurity in response to organizational change. Thus, educational change is likely to succeed only if as many communication channels as possible are opened up within and outside the school system and, above all, if there is full transparency in decision-making.

Table 4. The score for the short-term focus dimension

\begin{tabular}{|c|c|c|c|}
\hline Dimension & Items & $\begin{array}{l}\text { Average of } \\
\text { the values }\end{array}$ & $\begin{array}{l}\text { Standard } \\
\text { deviation }\end{array}$ \\
\hline \multirow{4}{*}{$\begin{array}{l}\text { SHORT-TERM } \\
\text { FOCUS }\end{array}$} & $\begin{array}{l}\text { The pressure for change } \\
\text { exerted by managers creates } \\
\text { a tendency for me to resist, } \\
\text { although change can bring } \\
\text { me benefits in the end. }\end{array}$ & 3,53 & 1,10 \\
\hline & $\begin{array}{l}\text { The change of plans seems } \\
\text { to me a real trouble }\end{array}$ & 3,78 & 0,95 \\
\hline & $\begin{array}{l}\text { Sometimes I find myself } \\
\text { shying away from change, } \\
\text { even though I know it will } \\
\text { be good for me. }\end{array}$ & 3,92 & 0,80 \\
\hline & $\begin{array}{l}\text { Sometimes I even question } \\
\text { the changes that could } \\
\text { improve my life. }\end{array}$ & 4,12 & 0,50 \\
\hline
\end{tabular}


In the context of the Coronavirus pandemic, the major changes that have taken place in all aspects of life: social, economic, educational, cultural and health have created the premises for a rethinking of the educational approach from day to day, in order to identify new ideas and resources to perform a quality educational act.

The high score on the short-term concentration subscale should therefore be a wake-up call for education managers as the need for entrepreneurial thinking has emerged, based on the search for response and the exploitation of change, considered as an opportunity, so a flexible activity, long-term adaptability and creativity.

Table 5. The score for the cognitive rigidity dimension

\begin{tabular}{clcc}
\hline Dimension & \multicolumn{1}{c}{ Items } & $\begin{array}{c}\text { Average of } \\
\text { the values }\end{array}$ & $\begin{array}{c}\text { Standard } \\
\text { deviation }\end{array}$ \\
\hline & $\begin{array}{l}\text { I persist in the decisions I } \\
\text { make }\end{array}$ & 4,29 & 0,45 \\
COGNITIVE & $\begin{array}{l}\text { I often change my mind } \\
\text { RIGIDITY }\end{array}$ & 2,07 & 0,67 \\
& $\begin{array}{l}\text { Once I come to a } \\
\text { I keep my opinions over } \\
\text { time }\end{array}$ & 4,46 & 0,49 \\
& 4,58 & 0,49 \\
\hline
\end{tabular}

Cognitive rigidity implies a tendency to keep your views tenacious, being in fact a form of unavailability to consider alternatives or opinions.

In the current education system in Romania there is established the idea that cognitive rigidity is a proof of strength, resistance to manipulation and influence. This concept runs counter the need for such an acute change in the Romanian school, in which teachers-entrepreneurs are needed as the main driver of educational development, because they generate growth and serve as a vehicle for change and innovation.

The terms "change" and "entrepreneurship" have become increasingly used in the education system, as they tend to be associated with the well-being of a nation and economic development, and their use in the field of education is of a recent nature. Nowadays, the basis of economic, social and cultural development are: knowledge, innovation and entrepreneurship (State, 2020). 
Ana-Maria NICOLAE (STAN) | Lumen Proceedings 15 | GEKoS 2021

Table 6. Statistical comparative indices by dimensions

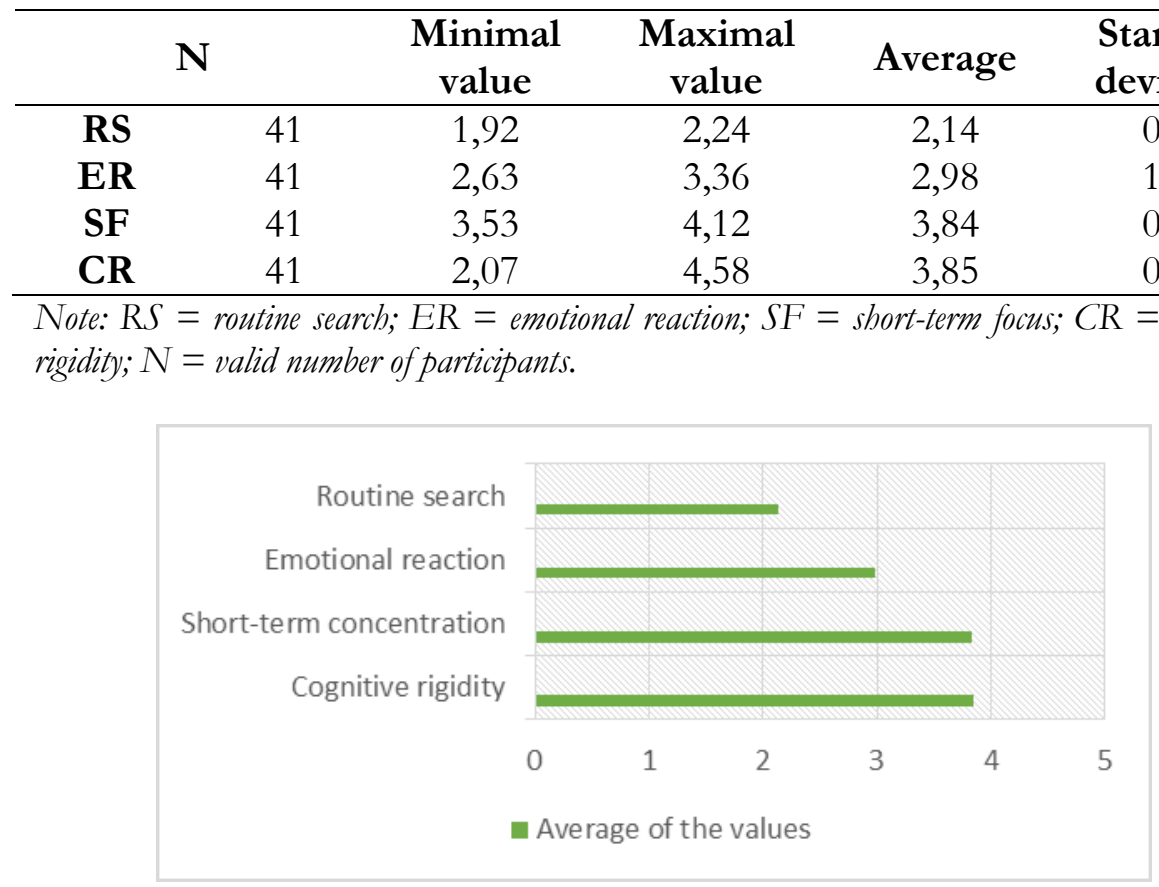

Figure 1. Distribution of statistical media by dimensions

It is distinguished that the values obtained by our sample of subjects are higher than the averages reported from other studies. This is due to the small number of subjects, as well as the unequal ratio between the male and female population surveyed.

Among the factors generating resistance to change, the highest weight is cognitive rigidity $(3,85)$, followed closely by the short-term focus $(3,84)$, which is due both to the dogmatism of the education system and to the rigidity and reluctance of teachers to change. The weight of the other two dimensions - emotional response $(2,98)$ and routine search $(2,14)$ should not be neglected, as they bring in the foreground the fear of change itself, of loss of rituals.

In this context, as Harkine (2017) points out "the confusion and inherent uncertainties, the fear of not rising to the new standards must be recognized, affirmed and counteracted by constant communication" so that the process of organizational change will lead the steps of human resources from the passive, familiar state, routine in the active, creative, entrepreneurial state. 


\section{Discussions}

People who are resilient to change can engage in impressions management behaviors to minimize or eliminate the effect of change in their work. When faced an imposed change, an individual who has an emotional response to change may choose to actively engage or oppose resistance.

In the current context, the failures and consequences of entrepreneurial activities faced by organizations are somehow ignored in scientific discussions (Gano-An \& Gempes, 2020). According to this field specialists, not all changes are improvements, but all improvements require changes. Effective change in any educational institution is not an easy-toachieve goal. Even if organizational changes are considered changes in the organization's technology, hierarchy, or structures, it is clear that change has an important impact on employees in educational organizations.

Most of the time, the reason why the process of organizational change fails is to underestimate the influence of change on the individual. Therefore, in order to successfully implement change, it is necessary to manage the impact of change on individuals, as a component and vital part of the organization.

\section{Conclusions}

The results of the study indicate that resistance to changing human resources in the education system is high.

Organizational change can be planned or spontaneous, individual or collective, imposed or participatory, but it will always raise the questions: "Will it work?", "Can it bring professional achievements and recognition?"(Fullan, 2007, p. 23). In school environments, people can show uncertainty, fear and frustration about change initiatives.

The results of this study have practical significance for managers when managing an organizational change or transformation. Anxiety, uncertainty and joy are essential to the subjective sense of educational change and are the ones that condition their success or failure.

Therefore, the adoption of an impression management behavior, operating as a barometer, to ascertain whether their effort of change is well received by the members of the organization could lead to the successful implementation of the change by shifting employees from passive to active status, from everyday routine to enthusiastic implementation of new entrepreneurial ideas. 
Ana-Maria NICOLAE (STAN) | Lumen Proceedings 15 | GEKoS 2021

\section{Acknowledgement:}

This work is supported by project POCU 125040, entitled "Development of the tertiary university education to support the economic growth PROGRESSIO", co-financed by the European Social Fund under the Human Capital Operational Program 2014-2020

\section{References}

Babbie, E. (1990). Survey research methods (2nd ed.). Wadsworth Publishing Company. Beckhard, R. (1975). Strategies for large system change. Sloan Management Review, 16(2), 43-55.

https://www.proquest.com/openview/8f6502b8f7f98c54842f4b673eb676 $\underline{\mathrm{f} 0 / 1 \text { ?pq-origsite }=\text { gscholar } \& \mathrm{cbl}=35193}$

Creswell, J. W. (2009). Research design: Qualitative, quantitative, and mixed methods approaches (3rd ed.). Sage.

Dutton, J. E., O'neill, R. M., \& Lawrence, K. A. (2001). Moves that matter: Issue selling and organizational change. Academy of Management Journal, 44(4), 716736. https://doi.org/10.2307/3069412

Foster, R. D. (2010). Resistance, justice, and commitment to change. Human Resource Development Quarterly, 21(1), 3-39. http://dx.doi.org/10.1002/hrdq.20035

Fullan, M. (2007). The new meaning of educational change (4th ed.). Teachers College Press

Gano-An, J., \& Gempes, G. P. (2020). The success and failures of sari-sari stores: Exploring the minds of women micro-entrepreneurs. HOLISTICA Journal of Business and Public Administration, 11(2), 25-51. http://dx.doi.org/10.2478/hjbpa-2020-0017

Gersick, C. J. G. (1991). Revolutionary change theories: A multilevel exploration of the punctuated equilibrium paradigm. Academy of Management Review, 16(1), 10-36. http://www.iot.ntnu.no/innovation/norsi-pims courses/tushman/Gersick\%20(1991).pdf

Harkine, M. (2017, June 6). 3 common obstacles to organisational change and how to overcome them. Leading teams. https://www.leadingteams.net.au/obstacles-tochange-overcome-them

Judge, T. A., Thoresen, C. J., Pucik, V., \& Welbourne, T. M. (1999). Managerial coping with organizational change: A dispositional perspective. Journal of 
Ana-Maria NICOLAE (STAN) | Lumen Proceedings 15 | GEKoS 2021

Applied Psychology, 84(1), 107-122.

https://psycnet.apa.org/doi/10.1037/0021-9010.84.1.107

Kotter, J. (2007, January). Leading Change - Why Transformation Efforts Fail.

Harward Business Review, 1-11. https://irp-

cdn.multiscreensite.com/6e 5 efd $05 /$ files/uploaded/Leading $\% 20$ Change.pd f

Kotter, J., \& Schlesinger, L. A. (1979). Chosing strategies for change. Harvard Business Review, 106-114.

https://projects.iq.harvard.edu/files/sdpfellowship/files/day3 2 choosin $g$ strategies for change.pdf

Nadler, D. A., \& Tushman, M. L. (1989). Organizational frame bending: Principles for managing reorientation. Academy of Management Executive, 3(3), 194-204. https://doi.org/10.5465/ame.1989.4274738

Oreg, S. (2003). Resistance to change: Developing and individual differences measure. Journal of Applied Psychology, 88(4), 680-693.

https://doi.org/10.1037/0021-9010.88.4.680

Oreg, S. (2006). Personality, context, and resistance to organizational change. European Journal of Work and Organizational Psychology, 75(1), 73-101. https://doi.org/10.1080/13594320500451247

Oxman, J. A., \& Smith, B. D. (2003, October 15). The limits of structural change. MIT Sloan Management Review. https://sloanreview.mit.edu/article/the-limitsof-structural-change/

Pruteanu, S. M. (2020). Ethics - A mandatory instrument to ensure good governance of the public sector. In A. Grigorescu \& V. Radu (vol. ed.), Lumen Proceedings: Vol. 11. 1st International Conference Global Ethics-Key of Sustainability (GEKoS) (pp.316-327). Iasi, Romania: LUMEN Publishing House. https://doi.org/10.18662/lumproc/gekos2020/32

Rosenblatt, Z. (2004). Skill flexibility and school change: A multi-national study. Journal of Educational Change, 5(1), 1-30.

http://dx.doi.org/10.1023/B:JEDU.0000022841.54071.36

Rusmingsih, D., Widarni, E. L., Bawono, S. (2021) Human psychological factors in the success of human capital investment in driving financial performance. HOLISTICA - Journal of Business and Public Administration, 12(1), 69-75. http://dx.doi.org/10.2478/hjbpa-2021-0007

Schein, E. H. (1992). Organizational culture and leadership (2nd ed.). Jossey-Bass. 
Ana-Maria NICOLAE (STAN) | Lumen Proceedings 15 | GEKoS 2021

Schein, E. H. (1996). Kurt Lewin's change theory in the field and in the classroom: Notes toward a model of managed learning. Systems practice, 9(1), 27-47. http://citeseerx.ist.psu.edu/viewdoc/download?doi=10.1.1.475.3285\&rep Erep1\&type $=$ pdf

Smollan, R. K. (2006). Minds, hearts and deeds: Cognitive, affective and behavioural responses to change. Journal of Change Management, 2(6), 143158. https://doi.org/10.1080/14697010600725400

State, M. (2020). The efficiency of entrepreneurial education programs in Romania. In A. Grigorescu \& V. Radu (vol. ed.), Lumen Proceedings: Vol. 11. 1st International Conference Global Ethics -Key of Sustainability (GEKoS) (pp. 65-73). Iasi, Romania: LUMEN Publishing House. https://doi.org/10.18662/lumproc/gekos2020/08

van Dam, K., Oreg, S., \& Schyns, B. (2008). Daily work contexts and resistance to organisational change: The role of leader member exchange, development climate, and change process characteristics. Applied Psychology: An International Review, 57(2), 313-334. https://doi.org/10.1111/j.14640597.2007.00311.x

Wanberg, C. R., \& Banas, J. T. (2000). Predictors and outcomes of openness to changes in a reorganizing workplace. Journal of Applied Psychology, 85(1), 132142. https://doi.org/10.1037/0021-9010.85.1.132

Zander, A. (1950). Resistance to change - its analysis and prevention. Advanced Management Journal, 15(1), 9-11. https://psycnet.apa.org/record/1950$\underline{06096-001}$ 